\title{
STUDENT'S PERSPECTIVES ON
}

\section{TOTAL QUALITY MANAGEMENT IN HIGHER EDUCATION}

\author{
Mr. Mayank Vyas
}

\begin{abstract}
This paper aims at examining students perspectives and perceptions towards implementation of Total Quality Management (TQM) in the context of students pursuing Master's Degree at The Maharaja Sayajirao University of Baroda. The rationale behind the inquire lies in the emergent need of the application of TQM in higher education of India for qualitative education that can compete with global education in the $21^{\text {st }}$ century.

The study is based on a sample survey of 462 respondents out of a population of 5898 by employing sample size determinants like: confidence level, confidence interval and population size. The convenience sampling technique is used. A survey questionnaire was administered to students pursuing Master's Degree in different Programmes of The Maharaja Sayajirao University of Baroda in person. The questionnaire covers factors like management commitment, student satisfaction, employee involvement and continuous improvement. 326 respondents are considered as valid respondents for further investigation. The study is qualitative research in nature and the collected data has been analyzed by scale reliability for questionnaire scaling validity, descriptive statistics, measurement of items, correlation, including other applicable statistical tests with a view to know whether management commitment has positive relationship with student satisfaction, employee involvement and continuous improvement. IBM SPSS.25 is employed for data analysis as a statistical tool.

The collected data reveals a positive relationship among management commitment, student satisfaction, employee involvement and continuous improvement with reference to the students of The Maharaja Sayajirao University of Baroda.

This study indicates the significance of TQM in higher education in India which can improve quality of education and can also compete at global level. Further research can be undertaken with more samples by extending the area of research.
\end{abstract}

Key Words: TQM, Higher Educational Institutions, Management Commitment, Student Satisfaction, Employee Involvement 


\section{Introduction}

Total quality management (TQM) is a way of managing to improve the effectiveness, efficiency, cohesiveness, flexibility and competitiveness of a business as a whole. As defined by British Standard Institution, TQM consists of "a management philosophy and company practices which aim to harness the human and material resources of an organization in the most effective way to achieve the objectives of the organization". Quality improvement has become a considerable force throughout the world. Although methods to improve and manage quality are numerous, it can be said that TQM is a critical determinant in the success of not only the manufacturing organizations, but also, Higher Education Institutions (HEls). Intensified global competition and increasing demand for higher quality in education have instigated an increasing number of HEls to invest substantial resources in adapting and implementing Total Quality Management procedures, tools and techniques.

Total Quality Management is defined as an integrative management philosophy and a set of guiding principles, representing the foundation of a continuously improving organization/institution. It constitutes the application of sound management principles, quantitative measurement methods and human resources with an underlying aspiration of improving all departments within an institution, surpassing the current and future needs of the stakeholders and increasing the overall performance.

Over the past few decades, eminent figures in the field of quality management, Deming and Juran, have developed and advocated abundant prescriptions in the area of Total Quality Management. Their insight into the field of Total Quality Management has provided a useful understanding of the underlying principles of Total Quality Management and has formed the basis against which subsequent researchers have formulated and verified critical success factors of Total Quality Management. Quality Management is a phrase that is used to encompass a vast array of tools, techniques and methodologies for continuous improvement. The present study aims to discuss students' perceptions of TQM and its effect on attractiveness of place of study.

The quality philosophy and principles have become central to international educational reform efforts in nations such as Canada, Australia, Japan, the United States and the United Kingdom (Weller, 1996). The attraction of TQM philosophy is mainly because of its successful record in the world of business in producing quality products and services. In fact, TQM provides a structured and comprehensive delivery system which may lead improvements in education (Weller and Hartley, 1994). TQM recognizes students as both customers and employees (Stake Holder) of the education system (Weaver, 1992). Therefore, the roles of students must be recognized by involving them in their own learning process. Furthermore, students' evaluation in TQM is very important and should be carried out throughout their studies so that corrective measures may be enforced continuously (Weaver, 1992). 


\section{Statement of the Problem}

In developing nations, the quality and social relevance of higher education is deteriorating due to several reasons. Total quality management is one of the important factors that shape the strategies of Higher Education Institutions in ensuring quality and continuous improvement. It has been successfully implemented in some Higher Education Institutions (HEls) and it is found to have improved the quality of higher education in those institutions. In view of the intent of The Maharaja Sayajirao University of Baroda, Vadodara, to undertake an assessment of the quality of its work, the present study seeks to conduct an evaluation of the University by the way of benchmarking with the TQM philosophy. In this context, this study identifies the importance of implementation of TQM and explores how the obstacles to its implementation can be overcome so as to improve the performance of the University and thereby, fulfill the expectations of the stakeholders.

\section{Importance of the Study}

In the present competitive scenario, HEls are forced to formulate and implement strategies within global context. Total Quality Management (TQM) has been described as a management philosophy and a way of thinking that has helped higher education institutions move towards achieving excellence in providing education. TQM helps create a culture of trust, participation, teamwork, quality-mindedness, zeal for continuous improvement, continuous learning and eventually, a working culture that contributes towards HEl's success and existence. TQM must be widely recognized and successfully implemented in HEl's, giving them the edge in international as well as local competitiveness, to ensure high quality services and satisfy the needs of stakeholders. HEl's must gain in-depth understanding of the key factors associated with the quality performance practices that is important to improve efficiency and enhance growth and sustainability

The students are stakeholders in HEls and their voice is important on quality education. Commitment to quality through total quality management will be helpful in the cultivation of practical education in the institutions of the country. Improvement in quality is never ending process. Education quality leads to a prospective future. There is a need of total quality management for quality in education at school level. Quality should be brought to the system in all aspects right from infrastructure to class room teaching, professional development and development of scientific temper. In order to compete in the global context, educational institutes particularly schools, Higher Educational Institution should promote quality education. In this paper, students' perceptions on TQM in context to The Maharaja Sayajirao University of Baroda is examined by considering factors like management commitment, student satisfaction, employee involvement and continuous improvement. 


\section{Review of Literature}

Abhijit Mehta, \& Faisal Rafik Degi (2019) ${ }^{1}$ conclude in article " Total quality management implementation, and its barriers in Education system" that institutional change environment, sustainable success, and innovation can be achieved by implementing TQM and committed management is necessary for this purpose.

Ahmed AbdulSalam Ahmed Al-Salim (2018) ${ }^{2}$ concludes in his article that strategic plans put by the management for innovation and quality education should match with international standards. The authors also conclude that changing environment and integrating on goal achievement are the most important components in any higher education institute.

S. Ramkumar $(2017)^{3}$ concludes in his article that the compliance and acceptance of quality systems improved as the faculty and staff started realizing its benefit both at the individual, departmental and the institute level after going through a full cycle of 3 years of ISO implementation. He also concludes that committed leadership with active cooperation of all the faculty, staff, students and organization-wide involvement is sure to usher spectacular results through adoption of TQM approach.

Zaid Ahmat $(2015)^{4}$ has focused on TQM elements of University Education through environmental factors. He asserts that TQM is a very important factor to provide quality education service to the students. It helps to increase the performance of the University so that researchers specially concentrate on the principles of TQM in higher education institutions. According to the researcher TQM is required for the learning process to achieve academic excellence in Universities. Their discussion is based on the literature review and they concluded that TQM is a major strategy to focus on students, staff, and employee to get quality output in higher education institutions.

Chahal Mukesh $(2015)^{5}$ has mainly focused on the overall performance of higher education in India. He has explored the initiatives taken by the Government to raise the level of higher education system in India. He draws the conclusions on the requirements of Indian higher education system as being the need for proper plans to combine employers and youth in India to satisfy the expectations of various stakeholders like student, industry, parents and government, etc.

Goel M.M. and Walia Suraj $(2015)^{6}$ have discussed the Indian higher education and its trends, growth and challenges. According to them higher education promotes social and economic development of any country. Indian higher education needs massive improvements in both qualitative and quantitative terms. Indian higher education is facing problems of access, equity, privatization and financing. This requires appropriate policy formulation and their proper implementation in the higher educational institutions.

Ghosh Subrata and Barman Arup $(2014)^{7}$ have examined how higher education be a means to provide directions and ways for inclusive social development. They assert that economic growth, human right, employment, income generation, health, etc., are developed by higher education. Sustainable development is possible through quality higher education. However, a major portion of poor and marginalized people are being deprived of higher education in India. Using secondary data the researchers show that socio-economic disparity can be 
eliminated by the higher education system and action-based approach is more suitable for the same.

Vishwanathan C.N. (2014) ${ }^{8}$ has presented his work on the total quality management in the higher education in Kerala. He asserts that TQM is essential for continuous improvement rather than a once-for-all affair. He finds that the standard of Indian higher education institutions is very low and compares poorly with many other systems of the world. Undertaking a case study of the higher education system in the state of Kerala, the researcher has examined the state of higher education system in Kerala. The study is based on a mix of primary and secondary data of Arts, Science and Commerce Colleges in Kerala, which are affiliated to the University of Kerala, University of Calicut, Mahatma Gandhi University and Kannur University. The researcher has employed simple random sampling and simple arithmetic and statistical measures and methods for analyzing the data. His findings show deterioration in the quality of higher education system in Kerala. The researcher has delved into the causes for its quality deterioration.

Pillai \& Garg $(2013)^{9}$ have studied the attitude and perception of Management students toward Ethics in Marketing, and find that students consider ethics in marketing as a very important point for discussion and that the subject of marketing and allied subject cover ethics inadequately, and indicated that most respondents felt that the existing teaching in business school does not cover ethics in marketing the way it should.

Palak Kakkar $(2017)^{10}$ has examined the impact of TQM on earning recognition for the HEls which in turn significantly increases the motivation levels of the staff and adds to the goodwill. This holds immense importance in view of the various opportunities available to Institutions earning high grades from accreditation agencies. But there is no surety that a rank holder will perform consistently better in the future. Also, there is no consensus about what constitutes the basic characteristics of a rank holder. Total Quality Management is a comprehensive and structured approach to organizational management that seeks to improve the quality of products and services through ongoing refinements in response to continuous feedback. In short TQM is the organizational commitment to meet or exceed customer expectations. The primary objective of TQM is thus, customer satisfaction. TQM can be applied to any type of system, even in the educational set ups and teaching-learning events. The potential benefits of using TQM in higher and technical education lie in the provision of better service to its primary customers, the students, as well as secondary customers.

Tyagi (2014) ${ }^{11}$ in her study related to the implementation of TQM in education for the better solution concluded that TQM can be implemented for achieving excellence in the education institutions, i.e. schools, higher education and universities and that it is the job of top management to provide a way for continuous improvement of the system. It requires teamwork, training, collaboration and following the TQM cycle properly.

Gopinathan $(2014)^{12}$ opined that the quality education was largely associated with the development of human resources, focused at developing competencies and capabilities. He synthesized the process of quality assurance based on accreditation and accountability, autonomy and academic freedom, technology and infrastructure facilities. 
Mark $(2013)^{13}$ suggested that student satisfaction achieved by "embedding quality in the learning process" was necessary for higher education institutions to remain competitive. Both preconditions, namely, organization-wide employee involvement and customer focus, serve to create an environment that is conducive for TQM

Asif et al., (2013) ${ }^{14}$ state that while TQM models identify a variety of critical factors, employee involvement and customer focus are two factors which continually emerge across many of the existing TQM studies as the most significant.

Salameh et al. (2011) $)^{15}$ tried to identify the requirements for implementing TQM in the Faculty of Planning and Management at Al-Balqa Applied University. Their results showed that the adoption of TQM was limited in Arab countries, particularly at higher education institutions. The results also indicated that there was a weakness in training for administrative leadership in the universities and colleges which is essential to the success of implementing TQM. Additionally, there was no concentration on teamwork, continuous improvement and coordination which lead to creativity and innovation.

N R Setty $(2007)^{16}$ observes that the implementation and practicing of TQM in technical education institutes not only enhances the quality of the degree/diploma holders but also make them to cultivate the practice of total quality management. Therefore, when they enter a job in an organization, they are already aware of TQM, have imbibed a few TQM practices and developed a commitment to quality. This makes it very easy for the company to implement and practice TQM well. Such a quality education also makes the individuals to communicate better with others and understand their activities. This is essential and becomes a strong competitive advantage, because in a company one section becomes a customer to the preceding section and a supplier to the succeeding section. Understanding and communication among them will not only bring harmony in the company but will help in achieving the desired quality and high productivity.

Baldwin, (2002) ${ }^{17}$ argues that there have been success stories of quality improvements within higher education, others report that the TQM methods attempted within their higher education institutions have been reduced in scope or dropped entirely.

Nixon (2001) ${ }^{18}$ indicates that one way to define quality is the way accrediting agencies do, by generally defining quality as improvement in student learning. Nixon goes on, however, to indicate that one problem in defining quality in education is the number of factors that influence student learning. Simply reviewing student satisfaction reports is not sufficient. Instead she recommends the use of a service model to measure quality on five dimensions:

(a) tangibles, or what facilities and equipment are available to students; (b) reliability, defined as how well the services promised align with the services received; (c) responsiveness, or how well the institution responds to student needs; (d) assurance, or the knowledge of employees and their courtesy towards others; and (e) empathy, the individualized and caring attention to student needs

Helms and Williams (2001) ${ }^{19}$ identify this system as a key challenge to TQM implementation in higher education. The tenure system generally has three components, teaching, research, and service, with the focus on research increased after tenure is achieved. They suggest that 
these three focal points of faculty performance may be at odds with student needs and expectations, resulting in what students perceive to be 'poor quality' education. They quote a Business Week survey of graduates, which indicated students perceived time spent in research resulted in poorer quality instruction. A shift towards student satisfaction could then be at odds to the tenure system, which may result in faculty resistance.

Kaplan and Norton $(2001)^{20}$ detail the city of Charlotte, North Carolina's BSC, which included measures such as competitive tax rates, maintaining AAA rating, increasing positive contacts between government officials and customers, and achieving a positive employee climate. For each of these measures, leaders established a goal and measured trends to track performance and make improvements where needed.

\section{Objectives of the Study}

In the context of the review of literature, the objectives of the present study are as under

(1) To study student perceptions on management commitment as a part of TQM in context to The Maharaja Sayajirao University of Baroda

(2) To study student perceptions on students`satisfaction as a part of TQM in context to The Maharaja Sayajirao University of Baroda

(3) To study student perceptions on employee involvement as a part of TQM in context to The Maharaja Sayajirao University of Baroda

(4) To study student perceptions on continuous improvement as a part of TQM in context to The Maharaja Sayajirao University of Baroda

(5) To determine the most influential variable to the students as a part of TQM in context to The Maharaja Sayajirao University of Baroda

\section{Research Questions}

RQ1: Is there positive relation between management commitment and student satisfaction? RQ2: Is there positive relation between management commitment and employee involvement?

RQ3: Is there positive relation between management commitment and continuous improvement?

\section{Hypotheses}

H01: No relation exists between management commitment and students` satisfaction

H02: No relation exists between management commitment and employee involvement H03: No relation exists between management commitment and continuous improvement 


\section{Research Methodology}

The present study is analytic type of study and is based on primary as well as secondary data source. The target population is the students pursuing Master's Degree of The Maharaja Sayajirao University of Baroda $(\mathrm{N}=5898)$. The factors considered for administering questionnaire to the respondents are management commitment MC, student satisfaction SS, employee involvement $\mathrm{El}$ and continuous improvement $\mathrm{Cl}$. Total items are $44(\mathrm{MC}=11, \mathrm{SS}=9$, $\mathrm{El}=13$ and $\mathrm{Cl}=11$ ). Invited respondents are 360 and received back as 350 completed. Response Rare is determined as $97.2 \%$. Convenience sampling technique is applied. The sample size is determined $(n=462)$ by considering confidence interval. Confidence level and population targeted. The following statistical formula has supported on finalization of sampling size

$$
S S=Z^{2 *}(p) *(1-p)
$$

Where: $Z=Z$ value (e.g. 1.96 for $95 \%$ confidence level) $\mathrm{p}=$ percentage picking a choice, expressed as decimal

( .5 used for sample size needed) $\mathrm{c}=$ confidence interval, expressed as decimal (e.g., . $04= \pm 4$ )

The collected data are analyzed by using IBMSPSS.25 as a statistical tool. Pearson correlation test is conducted for the purpose of hypotheses testing including descriptive statistics, scale reliability test and other applicable pre-tests. The data are standardized before getting its further process for analysis.

\section{Discussion}

The demographic profile of respondents is associated with students who are pursuing Master's Degree in the context to The Maharaja Sayajirao University of Baroda, The tables of annexure are interpreted in the following manner.

Table-1 indicates the results on descriptive statistics of Management Commitment ( $\left.\mathrm{MC}_{1-11}\right)$. All the 11 items are showing the results on minimum and maximum respondents on scaling (i.e. SDA -SA), mean, standard deviation and variances $=462$. The range of mean for all the items is between $1.19-2.8$. The range of SD is for all the items are between 1.36-1.96. The range of variance is registered as 1.16-2.76. It indicates that the researcher can move for the further analysis for expected outcomes.

Table-2 indicates the results on descriptive statistics of Student Satisfaction (SS $1-9)$. All the 9 items are showing the results on minimum and maximum respondents on scaling (i.e. SDA $S A$ ), mean, standard deviation and variance. $S=462$. The range of mean for all the items is between $1.02-2.12$. The range of SD is for all the items is between 1.02-1.66. The range of 
variance is registered as 1.00-2.3. It indicates that the researcher can move for the further analysis for expected outcomes

Table-3 indicates the results on descriptive statistics of Employee Involvement $\left(\mathrm{El}_{1-13}\right)$. All the 13 items are showing the results on minimum and maximum respondents on scaling (i.e. SDA -SA), mean, standard deviation and variance. $s=462$. The range of mean for all the items is between 1.4-2.1. The range of SD is for all the items is between 1.0-1.66. The range of variance is registered as 1.00-2.3. It indicates that the researcher can move for the further analysis for expected outcomes

Table-4 indicates the results on descriptive statistics of Continuous Improvement $\left(\mathrm{Cl}_{1-13}\right)$. All the 11 items are showing the results on minimum and maximum respondents on scaling (i.e. SDA -SA), mean, standard deviation and variance. $s=462$. The range of mean for all the items is between 1.2-2.9. The range of SD is for all the items is between 1.0-1.74. The range of variance is registered as 1.00-2.5. It indicates that the researcher can move for the further analysis for expected outcomes.

Table-5 of annexure shows on results on scale reliability of scaling technique.5-point Likert scale (strongly disagree to strongly agree) has been applied. Scale reliability is commonly said to limit validity (John \& Soto, 2007). Improper use of alpha can lead to situations in which either a test or scale is wrongly discarded or the test is criticized for not generating trustworthy results. To avoid this situation an understanding of the associated concepts of internal consistency, homogeneity or uni-dimensional can help to improve the use of alpha. Internal consistency is concerned with the interrelatedness of a sample of test items. Internal consistency is a Cronbach's alpha reliability coefficient normally ranges between 0 and 1 . However, there is actually no lower limit to the coefficient. The closer Cronbach's alpha coefficient is to 1.0 , the greater the internal consistency of the items in the scale. Based upon the formula ${ }_{-}=r k /[1+(k-1) r]$ where $k$ is the number of items considered and $r$ is the mean of the inter-item correlations the size of alpha is determined by both the number of items in the scale and the mean inter-item correlations. George and Mallery (2003) ${ }^{21}$ provide the following rules of thumb: "_> $.9-$ Excellent, ${ }_{-}>.8-$ Good, $_{-}>.7-$ Acceptable, $_{-}>.6-$ Questionable, _> .5 - Poor, and_<.5 - Unacceptable". While increasing the value of alpha is partially dependent upon the number of items in the scale, it should be noted that this has diminishing returns. It should also be noted that an alpha of .8 is probably a reasonable goal. It should also be noted that while high value for Cronbach's alpha indicates good internal consistency of the items in the scale, it does not mean that the scale is one-dimensional. In this study, level of Cronbach alpha is in the range of 0.798- 0.895(MC To Cl). It reports on acceptable and good internal consistency of factors considered for the study.

Table-6 indicates the results on Pearson correlations amongst the four factors. Hypotheses are also tested and interpreted in the following manner.

$\mathrm{H}_{0} 1$ : No relations exist between management commitment and students`satisfaction

$H_{1} 1$ : Positive relations exist between management commitment and students` satisfaction 
In table-7, $n=462 ., r=.761$ and sig. $p$ value .000 which is less than $0.05 . r=.761(76.1 \%)$ It means MC and SS are correlated with each other significantly. It means $\mathrm{H}_{0} 1$ vis rejected and $\mathrm{H}_{1} 1$ is accepted.

$\mathrm{H}_{0}$ 2: No relations exist between management commitment and employee indolent

$\mathrm{H}_{1}$ 2: Positive relations exist between management commitment and employee involvement.

In table-7, $n=462 ., r=.834$ and sig. $p$ value .000 which is less than $0.05 . r=.834(83.4 \%)$ It means $\mathrm{MC}$ and $\mathrm{El}$ are correlated with each other significantly. It means $\mathrm{H}_{0} 2 \mathrm{vis}$ rejected and $\mathrm{H}_{1} 2$ is accepted.

Ho3: No relations exist between management commitment and continuous improvement.

$\mathrm{H}_{13}$ : Positive relations exist between management commitment and continuous improvement.

In Table 6, $n=462 ., n=462, r=.720$ and sig. $p$ value .000 which is less than $0.05 . r=.720$ (72.0\%) It means $\mathrm{MC}$ and $\mathrm{Cl}$ are correlated with each other significantly. It means $\mathrm{H}_{0} 3$ is rejected and $\mathrm{H}_{1} 3$ is accepted.

\section{Conclusion}

The three objectives are satisfied by considering the above discussion. It can be concluded from the above discussion that management commitment is correlated with student satisfaction and continuous improvement. The issues related with student development, performance measures, quality awareness programs, interdisciplinary program, corporate stake holder involvement in course design to increase employability, exchange program with other Institution and with industry, basic infrastructural facilities, quality of physical education, employability oriented course structure, club activities, parents involvement, industryinstitution interaction, rewards, hygienic canteen facility, good library and laboratory facility, staff attitude on quality education, quality circle programs, conferences, workshops and other activities, stakeholders' feedback and student empowerment are evaluated as important issues during this investigation. All are observed as correlated with each other as components of TQM. The management of The Maharaja Sayajirao University of Baroda can implement TQM for more qualitative education by incorporating the above aspects. 
Towards Excellence: An Indexed, Refereed \& Peer Reviewed Journal of Higher Education / Mr.

\section{Mayank Vyas/ Page 46-62}

\section{References}

Ahmed AbdulSalam Ahmed Al-Salim (2015) Total Quality Management Its Impact on the Performance of Educational Institutions, International Journal of Scientific and Research Publications, Volume 8, Issue 8, August 2018239 ISSN 2250-3153,

Asif, M., Awan, M. U., Khan, M. K, \& Ahmad, N. (2013). "A model for total quality management in higher education," Quality and Quantity, 47: 1883-1904.

Baldwin, L. M. (2002). Total Quality Management in higher education: The implications

Boston: Harvard Business School Press. Change, 30(3), 10-15.

George, D. \& Mallery, P. (2003). SPSS for Windows step by step: A simple guide and reference. 11.0 update (4th ed.). Boston, MA: Allyn \& Bacon.

Gopinathan, Quality Assurance: A Benchmark in Higher Education, University News, 52(31)August 4-10,.2014

Helms, M.M., Williams, A.B., \& Nixon, J.C. (2001). TQM principles and their relevance to higher education: the question of tenure and post-tenure review. The International Journal of Educational Management, 15(7), 322-331.

Kaplan, R. S., \& Norton, D. P. (2001). The strategy focused organization: How balanced

M. M. Goel \& Suraj Walia, (2015). "Indian Higher Education: Trends, Growth \& Challenges," Working papers Voice of Research

Mark, E. (2013). "Student satisfaction and the customer focus in higher education," Journal of Higher Education Policy and Management, 35(1): 2-10.

Mehta, A., \& Degi, F.R. (2019). Total quality management implementation, and its barriers in Education system, International Journal of Management, and Social Sciences Review (IJMSSR). Vol. 3, No. 1, pp.36-42 
Mrs. Mukesh Chahal(2015), Higher Education in India: Emerging Issues, Challenges and Suggestions, International Journal of Business Quantitative Economics and Applied Management Research,Volume-1 Issue-11

Nixon, J. C., Helms, M. M., \& Williams, A. B. (2001). Succeeding in the education of internal and external stakeholder perceptions. Digital Dissertations, $63(05 \mathrm{~A})$, Palak Kakkar(2017) An Empirical Study of TQM Accounting in Higher Education, Students as Customer Perspectives, International journal of Research, ISSN- 2350-0530(O), ISSN2394-3629(P) volume-5

S.Ramkumar(2015), Total Quality Management and Research Productivity - A Case Report,Informatics Journals, Volume 11, Issue 2, pp- 8-9

Salameh, R. S., Alzyadat, M. A., \&Alnsour, J. A. (2011). Implementation of (TQM) in the faculty of planning and management at Al-Balqa Applied University. International Journal of Business and Management, 6(3), 194-207scorecard companies thrive in the new business environment (1st Ed. ed.).

Shetty, N R (2007), Technical Education - Challenges and Opportunities, The Indian Journal of

Subrata Ghosha, Arup Barmanb(2014), Inclusive Human Resource Development through Higher Education -A System Approach, International Journal of Trade and CommerceIIARTC January-June 2014, Volume 3, No. 1

Technical Education, Vol.30 (1), Jan-Mar 2007, PP. 21-23.

Tyagi(2014) Implementing total Quality Management in Professional Educational Institutes in India, Advances In Management, 4, issue 4.

Vishwanath, W. (2014) Fishes of Manipur: At a Glance. Envis Centre Manipur New Letter News letter. 11(1).Jan-March. 
Towards Excellence: An Indexed, Refereed \& Peer Reviewed Journal of Higher Education / Mr.

Mayank Vyas/ Page 46-62

ZeidAhmat(2015). TQM implementation-putting theory into practice: examples of best practices in the Higher Education institutions. International Journal of Excellence in Education. 1 (1), 1-40.

\section{Annexure}

\section{Descriptive Statistics (Management Commitment:MC $\mathbf{M C}_{111}$ )}

Table 1

\begin{tabular}{|c|c|c|c|c|c|c|}
\hline & $\mathrm{N}$ & Minimum & Maximum & Mean & Std. Deviation & Variance \\
\hline $\mathrm{MC1}$ & 462 & 1.00 & 3.00 & 3.4479 & 1.59901 & 1.359 \\
\hline MC2 & 462 & 1.00 & 5.00 & 3.8098 & 1.36123 & 1.853 \\
\hline MC3 & 462 & 1.00 & 5.00 & 2.6595 & 1.15963 & 1.587 \\
\hline MC4 & 462 & 1.00 & 5.00 & 3.6442 & 1.07789 & 1.633 \\
\hline MC5 & 462 & 1.00 & 5.00 & 4.4663 & .66144 & .760 \\
\hline MC6 & 462 & 1.00 & 5.00 & 3.8098 & 1.10133 & 1.264 \\
\hline MC7 & 462 & 1.00 & 5.00 & 3.9141 & 1.06332 & 1.228 \\
\hline MC8 & 462 & 1.00 & 5.00 & 2.9890 & 1.16722 & 1.152 \\
\hline MC9 & 462 & 1.00 & 5.00 & 3.7748 & 1.09784 & 1.154 \\
\hline MC10 & 462 & 1.00 & 5.00 & 4.0748 & .89784 & .954 \\
\hline MC11 & 462 & 1.00 & 2.00 & 4.1994 & 90015 & 860 \\
\hline Valid N (listwise) & 462 & & & & & \\
\hline
\end{tabular}


Towards Excellence: An Indexed, Refereed \& Peer Reviewed Journal of Higher Education / Mr. Mayank Vyas/ Page 46-62

Table-2

T

Descriptide Statistics Student Satisfaction: $\mathbf{S S}_{\mathbf{1 - 9}}$ )

b

I

2

\begin{tabular}{|lr|r|r|r|r|r|}
\hline & $N$ & Minimum & Maximum & Mean & Std. Deviation & \multicolumn{1}{|l|}{ Variance } \\
\hline SS1 & 462 & 1.00 & 5.00 & 3.0460 & 1.44042 & 1.075 \\
\hline SS2 & 462 & 1.00 & 5.00 & 4.7546 & .71575 & .878 \\
\hline SS3 & 462 & 1.00 & 5.00 & 2.6988 & 1.12606 & 1.053 \\
\hline SS5 & 462 & 1.00 & 5.00 & 4.1963 & .60522 & .577 \\
\hline SS6 & 462 & 1.00 & 5.00 & 3.5982 & 1.03831 & 1.433 \\
\hline SS7 & 462 & 1.00 & 5.00 & 4.5798 & .99139 & .983 \\
\hline SS8 & 462 & 1.00 & 5.00 & 4.6718 & .97961 & .960 \\
\hline SS9 & 462 & 1.00 & 5.00 & 4.8528 & .72076 & .744 \\
\hline $\begin{array}{l}\text { Valid N } \\
\text { (listwise) }\end{array}$ & 462 & 1.00 & 5.00 & 3.38528 & 1.32076 & 1.844 \\
\hline
\end{tabular}

Table-3

Descriptive Statistics (Employee Involvement: $\mathbf{E l}_{1-13}$ )

\begin{tabular}{|c|c|c|c|c|c|c|}
\hline & $\mathrm{N}$ & Minimum & Maximum & Mean & $\begin{array}{c}\text { Std. } \\
\text { Deviation }\end{array}$ & Variance \\
\hline El1 & 462 & 1.00 & 4.00 & 3.4325 & 1.261 & 1.437 \\
\hline EI2 & 462 & 1.00 & 5.00 & 3.4785 & 1.02484 & 1.050 \\
\hline EI3 & 462 & 1.00 & 5.00 & 3.1288 & 1.01768 & 1.303 \\
\hline El4 & 462 & 1.00 & 5.00 & 4.3834 & .88850 & .885 \\
\hline
\end{tabular}


Towards Excellence: An Indexed, Refereed \& Peer Reviewed Journal of Higher Education / Mr.

\begin{tabular}{|c|c|c|c|c|c|c|}
\hline \multicolumn{7}{|c|}{ Mayank Vyas/Page 46-62 } \\
\hline El5 & 462 & 1.00 & 5.00 & 3.0859 & 1.02072 & 1.313 \\
\hline El6 & 462 & 1.00 & 5.00 & 3.6319 & 1.11253 & 1.470 \\
\hline El7 & 462 & 1.00 & 5.00 & 3.6840 & 1.03595 & 1.528 \\
\hline El8 & 462 & 1.00 & 5.00 & 3.7025 & 1.12555 & 1.502 \\
\hline El9 & 462 & 1.00 & 5.00 & 3.5184 & 1.05450 & 1.112 \\
\hline El10 & 462 & 1.00 & 5.00 & 4.8190 & .70510 & .801 \\
\hline El11 & 462 & 1.00 & 2.00 & 4.4387 & .796 & .724 \\
\hline El12 & 462 & 1.00 & 5.00 & 4.9601 & .98958 & .766 \\
\hline El13 & 462 & 1.00 & 5.00 & 4.0491 & .81385 & .794 \\
\hline $\begin{array}{l}\text { Valid } N \text { (list } \\
\text { wise) }\end{array}$ & 462 & & & & & \\
\hline
\end{tabular}

Table-4

Descriptive Statistics (Continuous Improvement: $\mathbf{C l}_{1-11}$ )

\begin{tabular}{|c|c|c|c|c|c|c|}
\hline & $\mathrm{N}$ & Minimum & Maximum & Mean & Std. Deviation & Variance \\
\hline $\mathrm{Cl} 1$ & 462 & 1.00 & 5.00 & 3.2730 & 1.64152 & 1.550 \\
\hline $\mathrm{Cl} 2$ & 462 & 1.00 & 5.00 & 3.9387 & 1.60841 & 1.587 \\
\hline $\mathrm{Cl} 3$ & 462 & 1.00 & 5.00 & 4.6687 & .93814 & .733 \\
\hline $\mathrm{Cl} 4$ & 462 & 1.00 & 5.00 & 4.9387 & .85395 & .832 \\
\hline $\mathrm{Cl} 5$ & 462 & 1.00 & 5.00 & 3.9448 & 1.15160 & 1.262 \\
\hline $\mathrm{Cl} 6$ & 462 & 1.00 & 5.00 & 3.9663 & 1.38856 & 1.428 \\
\hline $\mathrm{Cl} 7$ & 462 & 1.00 & 5.00 & 2.9663 & 1.48856 & 1.628 \\
\hline
\end{tabular}


Towards Excellence: An Indexed, Refereed \& Peer Reviewed Journal of Higher Education / Mr.

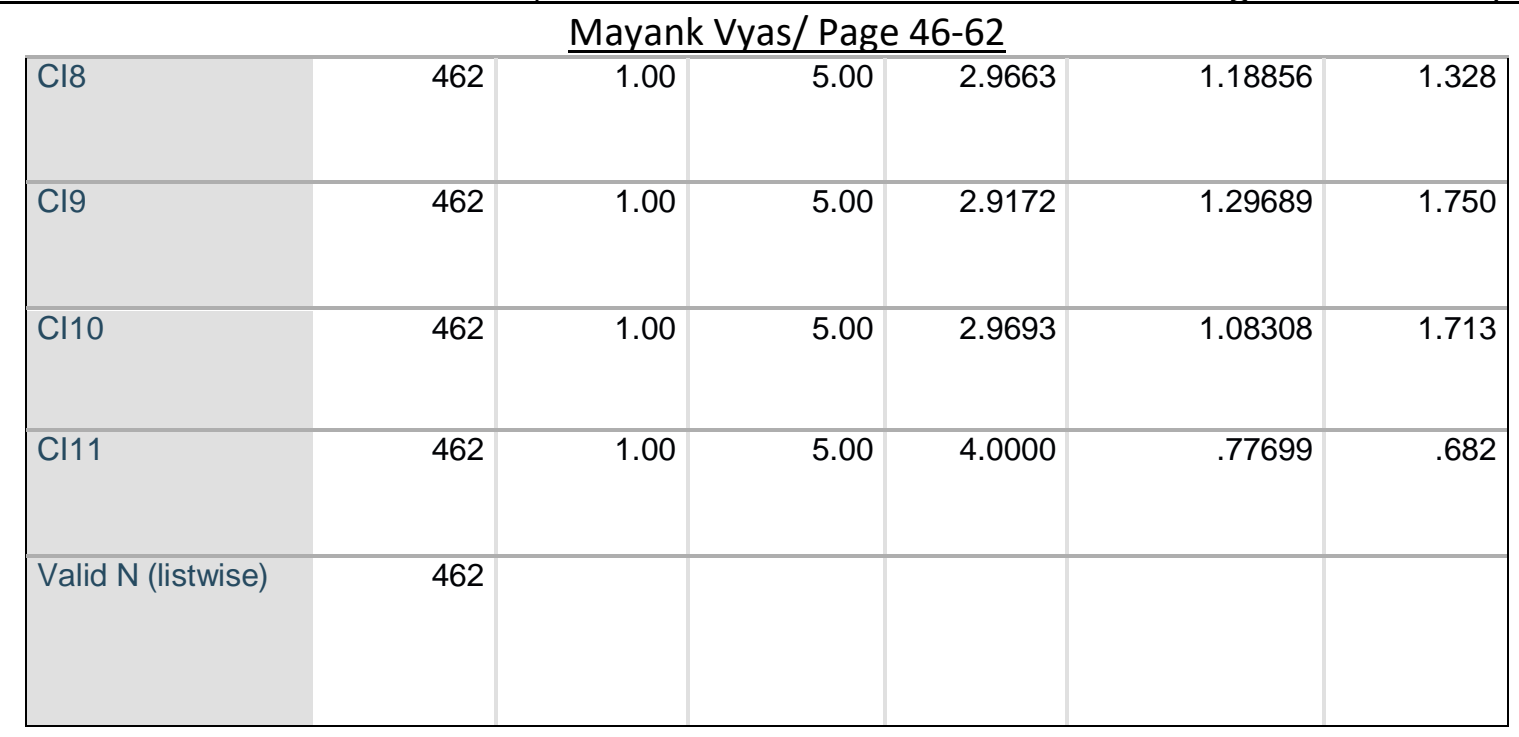

\section{Scale Reliability Test}

Table-5

\begin{tabular}{|l|l|c|c|c|l|l|l|}
\hline $\begin{array}{l}\text { Sr. } \\
\text { no }\end{array}$ & Factor & Items & $\begin{array}{l}\text { Excluded } \\
\text { Items }\end{array}$ & $\begin{array}{l}\text { Valid } \\
\text { Item } \\
\text { s }\end{array}$ & $\begin{array}{l}\text { Measured } \\
\text { Cronbach } \\
\text { Alpha }\end{array}$ & $\begin{array}{l}\text { Standard } \\
\text { Internal } \\
\text { Consistency }\end{array}$ & Decision \\
\hline 1 & $\begin{array}{l}\text { Management } \\
\text { Commitment }\end{array}$ & 11 & 0 & 11 & 0.798 & $0.7 \leq \alpha<0.8$ & $\begin{array}{l}\text { Acceptab } \\
\text { le }\end{array}$ \\
\hline 2 & $\begin{array}{l}\text { Student } \\
\text { Satisfaction }\end{array}$ & 9 & 0 & 9 & 0.895 & $0.8 \leq \alpha<0.9$ & Good \\
\hline 3 & $\begin{array}{l}\text { Employee } \\
\text { Involvement }\end{array}$ & 13 & 0 & 13 & 0.829 & $0.8 \leq \alpha<0.9$ & Good \\
\hline 4 & $\begin{array}{l}\text { Continuous } \\
\text { Improvement }\end{array}$ & 11 & 0 & 11 & 0.889 & $0.8 \leq \alpha<0.9$ & Good \\
\hline
\end{tabular}

\section{Pearson Correlations}

\section{Correlations Table-6}

\begin{tabular}{|c|c|c|c|c|c|}
\hline & & $\mathrm{MC}$ & $\mathrm{SS}$ & EI & $\mathrm{CT}$ \\
\hline \multirow[t]{4}{*}{$\mathrm{MC}$} & Pearson & 1 & & & \\
\hline & Correlation & & & & \\
\hline & Sig. (2-tailed) & & & & \\
\hline & $\mathrm{N}$ & 462 & & & \\
\hline
\end{tabular}




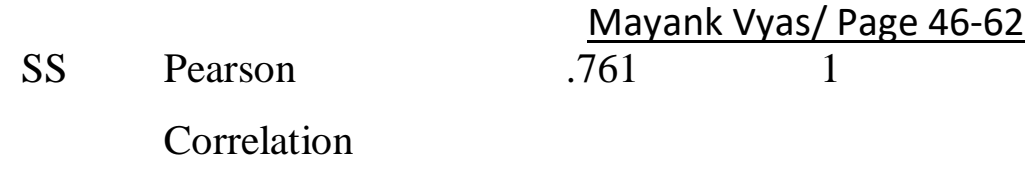

Sig. (2-tailed) $\quad .000 \quad .000$

\begin{tabular}{|c|c|c|c|c|}
\hline & $\mathrm{N}$ & 462 & 462 & \\
\hline EI & Pearson & .898 & $834^{* *}$ & 1 \\
\hline
\end{tabular}

\begin{tabular}{llllll} 
& Sig. (2-tailed) & .000 & .000 & .000 & \\
& $\mathrm{~N}$ & 462 & 462 & 462 & \\
\hline $\mathrm{CI} \quad$ & $\begin{array}{l}\text { Pearson } \\
\text { Correlation }\end{array}$ & .762 & .757 & $.720^{* *}$ & 1
\end{tabular}

$\begin{array}{lllll}\text { Sig. (2-tailed) } & .000 \quad 000 \quad 000 \quad .000\end{array}$

$\begin{array}{lllll}\mathrm{N} & 462 & 462 & 462 & 462\end{array}$

**. Correlation is significant at the 0.01 level (2-tailed).

\author{
Mr. Mayank Vyas \\ Ph.D Scholar \\ Faculty of Management Studies \\ The Maharaja Sayajirao University of Baroda, \\ Vadodara, Gujarat.
}

